\title{
IAMJ
}

INTERNATIONAL

AYURVEDIC

MEDICAL JOURNAL

\section{A REVIEW ON EFFECT OF PRANAYAMA ON MENTAL HEALTH DURING COVID-19}

\author{
$\operatorname{Varsha}^{1}$, Anita Sharma ${ }^{2}$, Sasmita Tripathy ${ }^{3}$ \\ PG Scholar ${ }^{1}$, Professor ${ }^{2}$, Lecturer $^{3}$ \\ PG Dept. of Swasthavritta and Yoga, Govt. Ayurved College, Raipur-492001, Chhattisgarh, India
}

Corresponding Author:Varsha.bams19@gmail.com

https://doi.org/10.46607/iamj1608122020

(Published online: December 2020)

Open Access

(C) International Ayurvedic Medical Journal, India 2020

Article Received:06/11/2020 - Peer Reviewed:14/11/2020 - Accepted for Publication:18/11/2020

\section{(D) Check for updates}

\begin{abstract}
The corona virus diseases 2019 (COVID-19) pandemic may be stressful for people. The COVID-19 pandemic is a major health crisis affecting several nations. Such widespread outbreaks are associated with adverse mental health consequences. Preliminary evidence suggests that symptoms of anxiety and depression (16-28\%) and selfreported stress $(8 \%)$ are common psychological reactions to the COVID-19 pandemic and may be associated with disturbed sleep. A number of individual and structural variables moderate this risk. In planning services for such population, both the needs of the concerned people and the necessary preventive guideline must be taken into account. The available literature has emerged from only a few of the affected countries and may not reflect the experience of persons living in other parts of the world. Fear and anxiety about a new disease and cause strong emotions in adults and children. Public health actions, such as social distancing, can make people feel isolated and lonely and can increase stress and anxiety. However, these actions are necessary to reduce the spread of COVID19. Mental health is an important part of overall health and wellbeing. It affects how we think, feel and act. It may also affect how we handle stress, relate to others and make choices during an emergency. Mental health problems are a common response to the COVID-19 pandemic. There is a need for more representative research from other affected countries, particularly in vulnerable populations.
\end{abstract}


Keywords: COVID-19, mental health, anxiety, depression, stress, public health

\section{INTRODUCTION}

Originating as a cluster of unexplained cases of pneumonia in Wuhan, China, novel corona virus disease - officially designated as COVID-19 by the World Health Organization - has reached the level of a pandemic, affecting countries all across the world. To date (March $30^{\text {th }}, 2020$ ), over 720,000 confirmed cases and 33,000 deaths attributable to this disease have been reported. In the wake of this global health crisis, stringent public health measures have been implemented to curtail the spread of COVID-19. [1]

Many psychological problems and important consequences in terms of mental health including stress, anxiety, depression, frustration, uncertainty during COVID-19 outbreak emerged progressively. ${ }^{[2]}$ Public health emergencies may affect the health, safety and well-being of both individuals (causing, for example, insecurity, confusion, emotional isolation and stigma) and communities (owing to economic loss, work and school closures, inadequate resources for medical response, and deficient distribution of necessities). These effects may translate into a range of emotional reactions (such as distress or psychiatric conditions). Some groups may be more vulnerable than others to the psychosocial effects of pandemics. In particular, people who contract the disease, those at heightened risk for it (including the elderly, people with compromised immune function, and those living or receiving care in congregate settings), and people with pre-existing medical, psychiatric, or substance use problems are at increased risk for adverse psychosocial outcomes. Health care providers are also particularly vulnerable to emotional distress in the current pandemic, given their risk of exposure to the virus, concern about infecting and caring for their loved ones, shortages of personal protective equipment (PPE), longer work hours, and involvement in emotionally and ethically fraught resourceallocation decisions. Beyond stresses inherent in the illness itself, mass home- confinement directives (including stay-at-home orders, quarantine and isolation). A recent review of psychological squeal in samples of quarantined people and of health care providers may be instructive; it revealed numerous emotional outcomes, including stress, depression, irritability, insomnia, fear, confusion, anger, frustration, boredom and stigma associated with quarantine, some of which persisted after the quarantine was lifted. Psychological assessment and monitoring should include queries about Covid-19 related stressors (such as exposures to infected sources, infected family members, loss of loved ones and physical distancing), secondary adversities (economic loss), and psychological effects (such as depression, anxiety, psychosomatic preoccupations, insomnia, increased substance use and domestic violence). The widening economic crisis and numerous uncertainties surrounding this pandemic, suicidal ideation may emerge and necessitate immediate consultation with a mental health professional or referral for possible emergency psychiatric hospitalization.

\section{Methodology}

\section{Characteristics of a Mentally Healthy Person}

Mental health is not mere absence of mental illness. A mentally healthy person has three main characteristics:

1. He feels comfortable about himself, that is, he feels reasonably secure and adequate.

2. The mentally healthy person feels right towards others. This means that he is able to be interested in others and to love them. He has friendships that are satisfying and lasting. He is able to like and trust others. He takes responsibility for his neighbours and his fellow men.

3. The mentally healthy person is able to meet the demands of life. He does something about the problems as they arise. He sets reasonable goals for himself. $\mathrm{He}$ shoulders his daily responsibilities. He is not bowled over by his own emotions of fear, anger, love or guilt. ${ }^{[3]}$ 


\section{DISCUSSION}

Causes of Mental Health Issues During Covid -19

Pandemic: The COVID-19 pandemic has caused stress, anxiety and worry for many individuals, arising both from the diseases and social distancing. Common causes of psychological stress during pandemics include, fear of falling ill and dying, avoiding health care due to fear of being infected while in care, fear of losing work and livelihoods, fear of being socially excluded, fear of being placed in quarantine, feeling of powerlessness in protecting oneself and loved ones, fear of being separated from loved ones and caregivers, refusal to care for vulnerable individuals due to fear of infection, feelings of helplessness, lack of self- esteem to do anything in daily life, boredom, loneliness and depression due to being isolated and fear of re-living the experience of a previous pandemic. ${ }^{[4]}$

\section{Effects of Covid-19 on Mental Health}

It is well known that pandemics pose a threat to mental health. Correspondingly, 2 recent reviews found a consistently negative impact of COVID-19 on mental health, with $16-18 \%$ of participants showing symptoms of anxiety and depression. The first evidence indicates that women, younger people and those with a poor sleep quality are at an increased risk for mental health problems. Specific stressors included greater duration of confinement, having inadequate supplies, difficulty securing medical care and medications and resulting financial losses. [5] Mental disorders, improving links between community and hospital services, and providing accurate information to the general public in order to minimize maladaptive responses such as "panic" and paranoia regarding the disease and its transmission. ${ }^{[6]}$

\section{The Psychological Impact of Quarantine Related to} Covid-19 Infection: The modern world in which all individuals are able to rapidly travel and communicate has been rarely forced to the current social isolation and restrictions which are linked to feelings of frustration and uncertainty. Social distancing and important lockdown restrictions have been carried out first in China and later in most European countries where Italy and Spain experienced a tragic growth of the number of positive cases. ${ }^{[7]}$ Other studies reported a higher prevalence of subjects with psychological symptoms, emotional disturbance, depression, stress, mood alterations and irritability, insomnia, posttraumatic stress symptoms, anger and emotional exhaustion among those who have been quarantined. ${ }^{[8]}$

Mental Health Infrastructure and Challenges Ahead: In India, $10 \%$ of the population has common mental disorders and $1.9 \%$ of the population suffers from severe mental disorders. Schizophrenia, bipolar affective disorder (BPAD), depression, anxiety disorders, psychoses, phobia, suicide, mood disorders, neurotic or stress related disorders, post-traumatic stress disorder, marital disharmony, sleep disorders, alcohol dependence and substance misuse and dementia are becoming common problems in the general population. ${ }^{[9]}$

\section{Which Groups Are at High Risk for Developing} Stress and Anxiety??

According to the Centres for Diseases control and Prevention (CDC), groups like the elderly ( $>65$ years), people with underlying medical conditions (diabetes, high blood pressure, heart disease, kidney disease etc.), people with pre-existing mental health issues, pregnant woman, children/teenagers and young people may develop and react strongly to stress and anxiety. Additionally, frontline stafflike healthcare providers, socially isolated people, alcoholic or substance addicts and homeless people were added in the group. Importantly, other health measures may be compromised by abnormally elevated anxiety. ${ }^{[9]}$ The healthcare workers are at a significant risk of adverse mental health outcomes during the COVID-19 outbreak. Reasons for this include long working hours, risk of infection, shortages of protective equipment, loneliness, physical fatigue and separation from families. ${ }^{[10]}$

Pranayama: Word 'Pranayama' is made up of two words 'Prana' \& 'Ayama'. 'Prana' means breath, respiration, life, vitality, wind, energy or strength. 'Ayama' means lengthen, expand, stretch or restraint. This indicates the control over the breath. ${ }^{[1]}$

Pranayama literally "life-force control" are controlling techniques for shifting your consciousness, 
purifying mind and body and raising your potential. The Pranayama is the mid part of Patanjalis Astangayoga framework. In the event that one practice the Pranayama without a doubt he will get control over unnecessary musings Pranayama have 3 steps they are: 1. Pooraka (Inhalation) 2. Rechaka (Exhalation) 3. Kumbhaka (Retention). The following are safe and very useful types of Pranayama for depression, anxiety and for general wellbeing like Kapalabhati, Anuloma Viloma, Ujjayi, Bhastrika, Shitali, Sitkari, Suryabhedana and Bhramari.

Nadi Shodhana: Alternate nostril breathing: Balances the restrained life energy of the body and the two sides of the brain, calms the psyche and increases vitality; a good basic Pranayama for depression and emotional imbalances.

Surya Bheda: Right-Nostril Breathing- Especially good Pranayama for depression, with lassitude, dullness, difficulty in communication and removal from the external world.

Kapalabhati: "Skull shining breath", "Frontal Brain Cleansing Breath"- (Another tremendous practice of pranayama for depression, particularly when anxiety is present; good for calming the mind and body).

Bhastrika: "Bellows Breath" - (A very effective Pranayama for depression and anxiety; detoxifies the body and purifies the mind; creates internal heat and stimulates metabolism; good for weight loss; Balances and strengthens the nervous system, inducing a peaceful and focused state of mind).

Ujjayi Pranayama: "Victory Breath" "Ocean Breath" or "Psychic Breath"- This breath is very important and has several benefits. An excellent Pranayama for depression, anxiety and stress. Ujjayi is very calming and soothing to the nervous system and this type of breathing can be done during meditation, for added benefit and to extend the breath.

Results of Proper Pranayama Practice: If pranayama is practiced in a proper way, it is capable of curing all the diseases. One should practice Pranayama regularly with Satvika mind, so that the morbid matter present in Susumna nadi gets purified $\&$ the flow of Prana through it becomes regulated. ${ }^{[12]}$
Sympathetic/ Parasympathetic Activation: The yoga effects on sympathetic/parasympathetic activation and cardiovagal function. Some evidence that yoga promotes a reduction in sympathetic activation, enhancement of cardiovagal function, and a shift in autonomic nervous system balance from primarily sympathetic to parasympathetic. ${ }^{[13]}$

\section{COCLUSION}

The study revealed that Covid-19 is creating psychological distress among the individuals, as there are restrictions due to lockdown people are forced to stay home. Individuals are going through a crisis situation and feeling lack of control on their lives due to lockdown and restrictions imposed upon them. Young adolescents and adult age group is facing uncertainty with respect to career and professional life, jobs are at stake. Fear of infection is creating a panic situation among them

There is increase in levels of Anxiety, stress and Depression specially among young group i.e. 15-35 years however, the previous studies have shown that the Anxiety, stress and Depression are more prevalent in older age group i.e.40-49 years age range. The study is in tune with the findings of National mental health survey of India 2016 which suggested that Anxiety is higher in females whereas males are depressed and stressed as compared to females. There is a significant difference between those who are employed and those unemployed in respect to stress and depression whereas in case of anxiety there is no significant difference between both.

\section{REFERENCES}

1. Ravi Philip Rajkumar, COVID-19 and mental health: A review of the existing literature, Elsevier Public Health Emergency Collection, 2020

2. Duan L, Zhu G. Psychological interventions for people affected by the COVID-19 epidemic. Lancet Psychiatry 2020

3. K. Park Textbook of Preventive and Social Medicine, $\mathrm{M} / \mathrm{s}$ Banarsidas Bhanot Publishers, $20^{\text {th }}$ edition, 2009, pg. no. 735 
4. Inter - Agency Standing Committee Guidelines on Mental Health and Psychosocial support, 31 March 2020

5. Brooks SK, Webster RK, the psychological impact of quarantine and how to reduce it: rapid review of the evidence, 2020, pg.no.912-920.

6. Lima C.K.T., Carvalho P.M.M., The emotional impact of Corona virus 2019-nCoV (new corona virus disease) Psychiatry Res. 2020, pg.no.287

7. https:// covid 19.who.int/18 May 2020

8. G Serafini, The psychological impact of COVID-19 on the mental health in the general population, An International Journal of Medicine, Volume 113, Issue 8, August 2020, pg. no. 531-537

9. Hygiene and public health, Yash pal bedi, Anand publishing, Nawankot, Amritsar, $10^{\text {th }}$ edition, 1970

10. Rubin GJ, Wessely S. Corona virus: the psychological effects of quarantining a city. BMJ opinion 2020

11. Kang L., The mental health of medical workers in Wuhan, China dealing with the 2019 novel corona virus, Lancet Psychiatry, 2020

12. Swasthavritta Textbook, Dr. Mangalagowri V. Rao, Chaukhambha Orientalia Varanasi, Edition 2017, pg no. 407

13. Hathyoga Pradipika, by Dr Sharvesh kumar Agarwal, Chaukhamba Orientalia, Varanasi 2013, pg.no.50

14. K.E. Innes, C. Bourguignon, and A.G. Taylor, "Risk indices associated with the insulin resistance syndrome, cardiovascular diseases and possible protection with yoga: a systematic review," Journal of the American Board of Family Practice, Vol.18, no.6 pg.no.491-519, 2005

\section{Source of Support: Nil}

\section{Conflict of Interest: None Declared}

How to cite this URL: Varsha et al: A Review On Effect Of Pranayama On Mental Health During Covid-19. International Ayurvedic Medical Journal \{online\} 2020 \{cited December, 2020\} Available from: http://www.iamj.in/posts/images/upload/5305_5309.pdf 